\title{
Flauelskjóllinn ${ }^{1}$
}

Ђegar við komum að húsinu með garðinum í Ayacucho-götu vorum við orðnar sveittar, og við bleyttum vasaklútana í gosbrunninum parna í Recoleta-hverfinu og strukum peim yfir enni okkar.

Við fórum í lyftunni upp á fjórðu hæð. Ég var í vondu skapi af pví að mig langaði ekki í pessa ferð, kjóllinn minn var skítugur og sîđdegis ætlaði ég að pvo og strauja rúmábreiðuna mína. Við hringdum dyrabjöllunni, einhver opnaði dyrnar og okkur var boðið inn. Casilda og ég gengum inn í íbúðina með pakkann. Casilda er saumakona. Við búum í Burzaco og ferðirnar í höfuðborgina preyta hana, sérstaklega pegar fara parf í hverfið í norðurhlutanum, pað er svo mikið úr leið. Casilda bað strax um vatnsglas svo hún gæti tekið höfuðverkjatöfluna sína sem hún var með í buddunni. Hún missti töfluna á gólfið, ásamt glasinu og buddunni. Pað var fyndið!

Við gengum upp teppalagðan stiga (sem lyktaði eins og mölkúlur) á eftir pjónustukonunni sem fór með okkur að svefnherbergi frú Corneliu Catalpina. Pað var nafn sem ég átti erfitt með að muna. Svefnherbergið var allt rautt með pykkum hvítum gluggatjöldum og parna voru speglar með gylltum römmum. Við biðum í heila eilífó eftir að húsfrúin kæmi út úr herberginu við hliðina par sem við heyrðum hana skola kverkarnar og tala við einhverjar raddir. Ilmvatnið hennar barst fram til okkar og rétt á eftir kom hún angandi af öðrum ilmi. Hún barmaði sér um leið og hún heilsaði okkur:

- Mikið eruð pið heppnar að búa í útjaðri Búenos Aíres! Pað er að minnsta kosti ekki sót par. Eru kannski flækingshundar og brenn-

1 Pýtt eftir texta í: Silvina Ocampo, La furia, Buenos Aires: Emecé, 1959. 
andi sorp par? ... Sjáið pið rúmteppið mitt. Haldið pið að pað sé grátt? Nei. Pað er hvítt. Eins og snjóbreiða. Hún tók um hökuna á mér og bætti við: - Pú hefur ekki áhyggjur af svona hlutum. En dásamlegur aldur! Átta ára, er pað ekki? Og nú sneri hún sér að Casildu og bætti við: - Af hverju seturðu ekki stein á höfuðið á henni svo hún stækki ekki? Unglegt útlit okkar ræðst af aldri barnanna.

Allir héldu að Casilda, sem var vinkona mín, væri mamma mín. раð var fyndið!

- Viltu ekki máta kjólinn, frú? sagði Casilda og opnaði böggulinn sem var festur saman með títuprjónum. Svo skipaði hún mér: Nádu í títuprjónana úr veskinu mínu.

- Máta kjóla! Рað er hreinasta kvöl! Mikið yrði ég hamingjusöm ef einhver vildi máta pá fyrir mig! Dað er svo preytandi.

Frúin fór úr fötunum og Casilda reyndi að klæða hana í flauelskjólinn.

- Hvenær hefst ferðalagið, frú mín? spurði hún og reyndi að beina athyglinni annað.

Konan gat ekki svarað. Kjóllinn komst ekki yfir axlirnar á henni: eitthvað sat fast í hálsmálinu. Pað var fyndið!

- Flauel festist svo auðveldlega við mann, frú, og pað er svo heitt í dag. Við skulum nota dálítið púður.

- Komið með pað, ég er að kafna, hrópaði frúin.

Casilda lyfti kjólnum upp yfir axlirnar og konan settist í hægindastólinn alveg að pví komin að falla í yfirlið.

- Hvenær hefst ferðalagið, frú mín? spurði hún aftur og reyndi að dreifa athygli frúarinnar.

- Pað styttist í pað. Рað er hægt að fara hvenær sem maður vill með flugvélunum sem eru til í dag. Kjóllinn verður að vera tilbúinn. Að hugsa sér að pað sé snjór par. Allt er hvítt, hreint og bjart.

- Ferðinni er heitið til Parísar, er pað ekki?

- Ég fer líka til Ítalíu.

- Geturðu mátað kjólinn aftur, frú mín? Dað tekur ekki nema örstutta stund.

Konan jánkaði og andvarpaði mæðulega.

- Lyftu báðum handleggjunum, pað er best að fara fyrst í ermarnar, sagði Casilda, og setti kjólinn aftur yfir höfuðið á henni.

Í dálitla stund reyndi Casilda að toga niður pilsið á kjólnum svo 
pað næði yfir mjaðmirnar á konunni, en án árangurs. Ég hjálpaði til eins og ég gat. Loksins tókst frúnni að komast í kjólinn. Uppgefin hvíldi hún sig andartak í hægindastólnum, stóð síðan á fæur til að spegla sig. Kjóllinn var gullfallegur og svo margbrotinn! Раð glampaði á útsaumaðan dreka með svörtum pallíettum vinstra megin á kjólnum. Casilda kraup niður, horfði á frúna í speglinum og tók að brjóta upp faldinn. Síðan reis hún á fæutur og stakk títuprjónunum í brotin á kjólfaldinum, hálsmálinu og ermunum. Ég snerti flauelið: pað var gróft pegar ég strauk hendinni í aðra áttina eftir pví en mjúkt pegar ég strauk pví í hina áttina. Ég fékk gæsahúð pegar ég kom við yfirborðið efnisins. Títuprjónarnir duttu á viðargólfið og ég tók pá hátî̉lega upp, einn og einn í einu. Pað var fyndið!

- Pað er aldeilis kjóll! Ég held að pað sé ekki til svona fallegt snið í allri Búenos Aíres, sagði Casilda og títuprjónninn sem hún var með á milli tannanna datt á gólfið. - Ertu ekki ánægð með hann, frú?

- Jú, alveg sérlega. Flauel er einmitt efnið sem ég hef mest dálæti á. Efni er eins og blóm: allir eiga sitt uppáhaldsblóm. Mér finnst flauel eins og liljur.

- Ertu hrifin af liljum? Pær eru svo dapurlegar, andmælti Casilda.

- Liljur eru uppáhaldsblómin mín, samt hafa pær slæm áhrif á mig. Mér verður ómótt pegar ég anda að mér ilmi peirra. Hárin rísa á höfdinu á mér af flauelinu og ég fæ gæsahúð, alveg eins og ég fékk af línhönskum pegar ég var lítil, samt er ekkert efni í heiminum sem jafnast á við pað. Mér finnst svo notalegt að finna mýkt pess á höndunum en um leið svo fráhrindandi. pað er ekki til betur klædd kona en sú sem klæðist svörtu flaueli! Pað parf ekki blúndukraga, hvað pá perlufesti; pví yrði ofaukið. Flauelið sjálft stendur fyrir sínu. Pað er ríkmannlegt en laust við allan íburð.

Pegar frúin lauk máli sínu átti hún erfitt með andardrátt. Einnig drekinn. Casilda sótti dagblaðið sem lá á borðinu og reyndi að kæla hana, en konan bandaði hendinni og bað hana að hætta af pví að kalt loft gerði henni ekki gott. Рað var fyndið!

Ég heyrði ópin í farandsölunum berast inn af götunni. Hvað voru peir að selja? Ávexti eða ís kannski? Ómurinn af flautinu í brýningarmanninum og klingjandi bjöllu íssalans færðist upp og niður götuna. Ég stökk ekki í forvitni að glugganum eins og ég var vön. Ég gat ekki slitið mig frá pví að horfa á frúna máta kjólinn með 
pallíettudrekanum. Hún stóð aftur á fætur og gekk riðandi að speglinum. Pallíettudrekinn riðaði líka. Kjóllinn var nú næstum orðinn fullkominn, aðeins aukafellingar undir báðum handleggjum sem sáust varla. Casilda tók aftur títuprjónana og nældi peim djarflega í aukafellingarnar á yfirnáttúrulegu efninu.

- Myndirðu ekki vilja vera í flauelskjól pegar pú verður stór? spurði frúin.

- Jú, svaraði ég, og fann hvernig flauelið í kjólnum prengdi að hálsinum á mér með hanskaklæddu höndunum sínum. Рað var fyndið!

- Nú fer ég úr kjólnum, sagði konan.

Casilda hjálpaði henni og hélt uppi kjólfaldinum.

Frúin rembist árangurslaust í nokkur andartök par til hún slétti aftur úr kjólnum.

- Ég verð víst að sofa í honum, sagði hún fyrir framan spegilinn og horfði á fölt andlit sitt og drekann sem skalf í takt við hjartslátt hennar. - Flauel er dásamlegt, en pað er pungt, sagði hún og bar höndina upp að enninu. - Petta er algert fangelsi. Hvernig kemst ég úr pví? Pað ætti að búa til kjóla úr óraunverulegu efni eins og lofti, ljósi og vatni.

- Ég myndi mæla með hrásilki, andmælti Casilda.

Pá féll konan á gólfið og drekinn engdist sundur og saman. Casilda laut yfir hana par til drekinn hætti að bæra á sér. Ég gældi enn einu sinni við flauelið sem var eins og dýr. Pá sagði Casilda dapurlega:

- Hún er dáin. Og ég sem lagði alla pessa vinnu í pennan kjól! Ég hafði svo mikið fyrir honum, svo mikið!

- Pað var fyndið!

Kristín Gudrún Jónsdóttir pýddi ür spansku 